$\operatorname{Tn} / 1 \times / 20$

2002064891

NASA/TM-2001-211215

AIAA-2001-3888

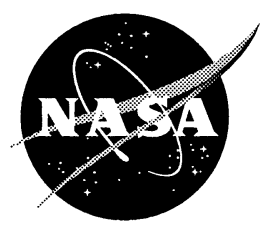

\title{
NASA's Hall Thruster Program
}

Robert S. Jankovsky, David T. Jacobson, Vincent K. Rawlin, Lee S. Mason, and Maris A. Mantenieks

Glenn Research Center, Cleveland, Ohio

David H. Manzella

University of Toledo, Toledo, Ohio

Richard R. Hofer and Peter Y. Peterson

QSS Group, Inc., Cleveland, Ohio 
Since its founding, NASA has been dedicated to the advancement of aeronautics and space science. The NASA Scientific and Technical Information (STI) Program Office plays a key part in helping NASA maintain this important role.

The NASA STI Program Office is operated by Langley Research Center, the Lead Center for NASA's scientific and technical information. The NASA STI Program Office provides access to the NASA STI Database, the largest collection of aeronautical and space science STI in the world. The Program Office is also NASA's institutional mechanism for disseminating the results of its research and development activities. These results are published by NASA in the NASA STI Report Series, which includes the following report types:

- TECHNICAL PUBLICATION. Reports of completed research or a major significant phase of research that present the results of NASA programs and include extensive data or theoretical analysis. Includes compilations of significant scientific and technical data and information deemed to be of continuing reference value. NASA's counterpart of peerreviewed formal professional papers but has less stringent limitations on manuscript length and extent of graphic presentations.

- TECHNICAL MEMORANDUM. Scientific and technical findings that are preliminary or of specialized interest, e.g., quick release reports, working papers, and bibliographies that contain minimal annotation. Does not contain extensive analysis.

- CONTRACTOR REPORT. Scientific and technical findings by NASA-sponsored contractors and grantees.
- CONFERENCE PUBLICATION. Collected papers from scientific and technical conferences, symposia, seminars, or other meetings sponsored or cosponsored by NASA.

- SPECIAL PUBLICATION. Scientific, technical, or historical information from NASA programs, projects, and missions, often concerned with subjects having substantial public interest.

- TECHNICAL TRANSLATION. Englishlanguage translations of foreign scientific and technical material pertinent to NASA's mission.

Specialized services that complement the STI Program Office's diverse offerings include creating custom thesauri, building customized data bases, organizing and publishing research results ... even providing videos.

For more information about the NASA STI Program Office, see the following:

- Access the NASA STI Program Home Page at http://www.sti.nasa.gov

- E-mail your question via the Internet to help@sti.nasa.gov

- Fax your question to the NASA Access Help Desk at 301-621-0134

- Telephone the NASA Access Help Desk at 301-621-0390

- Write to:

NASA Access Help Desk

NASA Center for AeroSpace Information 7121 Standard Drive

Hanover, MD 21076 
NASA/TM-2001-211215

\section{NASA's Hall Thruster Program}

Robert S. Jankovsky, David T. Jacobson, Vincent K. Rawlin, Lee S. Mason, and Maris A. Mantenieks

Glenn Research Center, Cleveland, Ohio

David H. Manzella

University of Toledo, Toledo, Ohio

Richard R. Hofer and Peter Y. Peterson

QSS Group, Inc., Cleveland, Ohio

Prepared for the 37th Joint Propulsion Conference and Exhibit cosponsored by the AIAA, SAE, AIChE, and ASME Salt Lake City, Utah, July 8-11, 2001

National Aeronautics and Space Administration

Glenn Research Center 


\section{Available from}

NASA Center for Aerospace Information 7121 Standard Drive

Hanover, MD 21076
National Technical Information Service 5285 Port Royal Road Springfield, VA 22100

Available electronically at http://gltrs.grc.nasa.gov/GLTRS 


\title{
NASA's Hall Thruster Program
}

\author{
Robert S. Jankovsky, David T. Jacobson, Lee S. Mason, Vincent K. Rawlin, and Maris A. Mantenieks \\ National Aeronautics and Space Administration \\ Glenn Research Center \\ Cleveland, Ohio 44135 \\ David H. Manzella \\ University of Toledo \\ Toledo, Ohio 43606 \\ Richard R. Hofer and Peter Y. Peterson \\ QSS Group, Inc. \\ Cleveland, Ohio 44135
}

\begin{abstract}
$\underline{\text { Abstract }}$
NASA's Hall thruster program has base research and focused development efforts in support of the Advanced Space Transportation Program, Space-Based Program and various other programs. The objective of the base research is to gain an improved understanding of the physical processes and engineering constraints of Hall thrusters to enable development of advanced Hall thruster designs. Specific technical questions that are current priorities of the base effort are: (1) How does thruster life vary with operating point? (2) How can thruster lifetime and wear rate be most efficiently evaluated? (3) What are the practical limitations for discharge voltage as it pertains to high specific impulse operation (high discharge voltage) and high thrust operation (low discharge voltage)? (4) What are the practical limits for extending Hall thrusters to very high input powers? and (5) What can be done during thruster design to reduce cost and integration concerns? The objective of the focused development effort is to develop a 50 $\mathrm{kW}$-class Hall propulsion system, with a milestone of a $50 \mathrm{~kW}$ engineering model thruster/system by the end of program year 2006. Specific program year 2001 efforts, along with the corporate and academic participation, are described.
\end{abstract}

\section{Introduction}

NASA's Hall thruster program is an integrated technology program addressing many NASA, DoD, and commercial customer requirements. The program is implemented through the OnBoard Propulsion Branch of the Power and OnBoard Propulsion Division at NASA Glenn Research Center (GRC). NASA's Hall thruster program began in the early 1990's when NASA, along with the Ballistic Missile Defense Organization, took great interest in Russian Hall thruster technology. The emphasis of this work was the evaluation of Russian technology with respect to potential missions, thruster performance, lifetime and integration issues. ${ }^{1-18}$

The conclusion of these evaluations was that Russian Hall thruster technology offered near optimal specific impulse and favorable thrust-topower with tractable integration concerns for many near Earth applications. NASA, and others, extrapolated these data to various power levels for use in spacecraft/mission design trade studies considering the advantages of increased spacecraft power for electric propulsion. Significant advantages were demonstrated. Specifically these studies showed Hall thrusters could enable new missions using existing launch vehicles or existing missions with a launch vehicle step down. Moreover, high power Hall thrusters with their unique combination of thrust and specific impulse were shown to offer significant benefits for missions when drag or gravity are major constraints. ${ }^{19-26}$ As a result of these studies the development of 10-50 kW Hall thruster systems became the technical objective of the NASA Hall thruster program.

To advance the technology necessary for these potential applications NASA initiated a 
comprehensive program that contained basic research and focused development efforts. The elements of this are illustrated in the work breakdown structure (WBS) in Figure 1. Program year 2001 funded efforts are described.

\section{Work Breakdown Structure}

The NASA Hall thruster program is divided into two categories: 1) base research and 2) focused development. As currently organized the base research element has five products areas and the focused element has two product areas. The base efforts address fundamental aspects of performance, cost, life, systems/integration, and thruster phenomenon. These efforts are at low technology readiness levels. The focused effort is directed towards mid technology readiness level development of 10-50 kW Hall thruster propulsion systems.

\section{Base Program}

The objective of the base research effort is to gain an improved understanding of the physical processes and engineering constraints of Hall thrusters to enable development of advanced Hall thruster designs. It is sponsored by a number of NASA Programs including the SpaceBased Program, the Advanced Space Transportation Program, the Space Solar Power Program, the Human Exploration and Development of Space (HEDS) Technology Commercialization Initiative, the Glenn Research Center Strategic Research Fund, and the Small Business Innovative Research Program.

Specific elements within the base portion of the Hall program are split into five areas: (1.1) Investigations into Extending the Performance Envelope, (1.2) Evaluation and Development of Lightweight/Low Cost Components, (1.3) Thruster Operational Life Assessment and Improvement, (1.4) Investigation of Innovative System Approaches/Integration Issues, and (1.5) Component Level Phenomenological Investigations.

\section{(1.1) Investigations into Extending the Performance Envelope}

A number of task level boxes are illustrated on the WBS in this area. However, in program year
2001 the task efforts were limited to (1.1.1) High Specific Impulse and (1.1.3) High Power tasks.

The high specific impulse task includes three efforts. The first effort considers a single-stage SPT-type thruster. The Atlantic Research Corporation and Fakel designed and built a derivative of the SPT-100 optimized for high voltage operation (Figure 2). The thruster operated satisfactorily and showed that near gridded ion thruster performance was possible. For example, at the target input power level of $2.3 \mathrm{~kW}, 97 \mathrm{mN}$ of thrust, 2900 seconds specific impulse and a total efficiency of $56 \%$ was demonstrated. ${ }^{27}$ At an elevated power level of $3.2 \mathrm{~kW}, 145 \mathrm{mN}$ of thrust were demonstrated with over 2500 seconds specific impulse and a total thruster efficiency of $55 \% .^{28}$ This performance is comparable to the state-of-the-art gridded ion thruster (NSTAR) performance of 91 $\mathrm{mN}$ of thrust, 3200 seconds specific impulse and total thruster efficiency of $62 \%$ at an input power of $2.3 \mathrm{~kW}$.

The second effort was a TAL investigation. The Boeing Company and TsNIIMASH designed and built a two-stage anode layer thruster or TAL (Figure 3). The two-stage TAL concept utilized a segmented anode with two power supplies to control the voltage distribution within the thruster. The concept was thought to separate the ionization and acceleration regions of the thruster allowing for optimization of each. Testing was conducted operating this device in both single-stage and two-stage modes. Data collected in the two-stage configuration revealed similar performance to single-stage performance at the same conditions. In the single-stage configuration, discharge efficiency of $57 \%$ and anode specific impulse of 2625 seconds was demonstrated at a discharge voltage and current of $700 \mathrm{~V}$ and $4.1 \mathrm{~A}$, respectively. ${ }^{29}$

The third effort in this task, performed by the University of Michigan and Glenn Research Center, is a two-stage SPT-type concept with an emitting electrode. This concept provides an additional source of electrons behind the peak magnetic field in order to optimize the ionization process independent of the accelerating process, making the thruster much more akin to a gridded ion thruster. The thruster was designated the P52 (Figure 4) because of it's heritage to the University of Michigan's single-stage P5. Other 
additions to this thruster include the $3 \mathrm{D}$ magnetic design of a plasma lens field line topology and the design of a radial trim coil to enable multimode operation through in-situ control of the magnetic field topology. Fabrication of this thruster has just been completed and functional testing has been initiated. Publication of the results is expected at the 2001 International Electric Propulsion Conference.

These investigations provide intermediate advances toward the high power multi-mode (very high thrust to very low thrust) Hall thrusters of the focused program. ${ }^{30}$ The results to date indicate that it is feasible to provide a Hall thruster with performance approaching that of gridded ion thrusters. The limiting mechanism in meeting or exceeding gridded ion thruster efficiency at specific impulses in excess of 4000 seconds appears to be the increased axial electron transport or the increased production of multiply charged ions at the discharge voltages needed to achieve these specific impulses. Evidence for this includes the changing relationship between discharge current and voltage above approximately $700 \mathrm{~V}$ and the decrease in efficiency. The concepts tested to date do not appear to offer a solution to this in the regimes tested.

Task (1.1.3), High Power, is an in-house Glenn Research Center effort. The task is an investigation into the limiting mechanisms when scaling Hall thrusters to high power, and an assessment of the practical limits in high power Hall thruster system development. In this task a $50 \mathrm{~kW}$-class Hall thruster is being designed and built. The design, designated the NASA-457M (Figure 5), has a design point of $500 \mathrm{~V}$ and 100 $\mathrm{A}$ and is estimated to produce approximately 2.5 $\mathrm{N}$ of thrust. The NASA-457M was designed for use as a test bed for high power Hall research. A unique aspect of this design is its large channel width. The channel dimensions are $457 \mathrm{~mm}$ outer diameter $\times 64 \mathrm{~mm}$ channel width. The large channel width reduces thruster size by maintaining current densities common to commercial Hall thrusters and will help to accommodate internal thruster diagnostics. The design is complete and fabrication is in progress. It is anticipated that the design and preliminary test results will be published at the 2001 International Electric Propulsion Conference.
(1.2) Evaluation and Development of Lightweight/Low Cost Components

In program year 2001 there is only one task in this element, (1.2.2) Non-traditional Fabrication Approaches. This task was selected as part of the Cross-Enterprise Technology Development Program NRA and is led by VACCO Industries, Inc. VACCO's Chemically Etched Miniature Systems or ChEMS ${ }^{\mathrm{TM}}$ technology is being investigated as a possible technique for creating low cost integrated propellant management assemblies. ChEMS ${ }^{\mathrm{TM}}$ technology consists of multiple layers of etched and bonded metal sheets to form components and their interconnecting flow paths. ${ }^{31}$ Figure 6 illustrates an integrated pressure and flow control unit capable of meeting many propulsion needs. The program has recently been initiated, and over the next three years will demonstrate functionality of an integrated pressure and flow control unit with a Hall thruster and gridded ion thruster.

\section{(1.3) Thruster Operational Life Assessment and Improvement}

In program year 2001, there are three tasks in the area of life assessment and improvement aimed at developing the tools and processes required for cost effective development of next generation Hall thrusters. Hall thrusters are being considered for applications where off nominal or multi-mode operation will be needed. The many possible operational mission scenarios being considered make it impractical to perform full lifetime qualification tests for each different case being considered. As a result, a method of scaling erosion/life from one set of qualification test data to many mission profiles without requalification is being sought. This area of work will be a large part of NASA's program in 2002. The three tasks described below are the initial stages of this effort. They are assessing the magnitude of the problem and developing tools for program year 2002 .

Task (1.3.1) Thruster sensitivity to operating point, is an investigation into the effects of thruster erosion with higher energy plasma from what is commonly practiced. In this task, the D80 from task 1.1.1 is being operated at a discharge voltage of $700 \mathrm{~V}$. The operating point was chosen for maximum performance in the thruster's thermally stable operating regime. A 
laser profilometery measurement technique is being used to periodically measure the geometry of the thruster's guard rings and electrodes (Figure 7). To date, the D-80 has been operated for 300 hours and testing is on-going. Testing is expected to be completed this summer and results published at the 2001 International Electric Propulsion Conference.

Simultaneously, task 1.3.6 is focussed on the development of in situ erosion diagnostics. The objective is to demonstrate an optical diagnostic for measurement of the relative amount of erosion products versus operating time. Current efforts are relying on emission spectroscopy of the plasma within the discharge chamber and near the exit of the thruster.

The third effort is task 1.3.3, Discharge Chamber Materials Influence. The influence of various ceramic discharge chamber materials on erosion rates and bulk performance is being investigated. Five different ceramic materials are currently being evaluated at the same operating conditions in a NASA-120M $2 \mathrm{~kW}$ Hall thruster. The materials initially selected include three different grades of boron nitride and two different boron nitride/silica compounds. Initial calculations indicated that a 200 hour test duration would be sufficient to assess erosion. The first specimen, HP grade boron nitride, has accumulated the 200 hour test duration and the next material is being installed in the thruster. Based on the results from initial testing, this effort is anticipated to be expanded in program year 2002 to include considerations of fabricability, cost, as well as the integration issues of contamination and thruster EMI.

(1.4) Investigation of Innovative System Approaches / Integration Issues

Task 1.4.2, Performance/Integration GroundSpace Correlation, is work remaining from the Advanced Space Transportation funded Future-X portion of the EXPRESS program. ${ }^{32,33}$ This work focuses on data analysis and reporting on in flight data from two Russian geostationary communication spacecraft presently in orbit, EXPRESS A2 and A3 (Figure 8a). These two spacecraft have a number of plasma probes mounted at various locations on their structures. These plasma probes are designed to measure ion current, and ion energy. Data from these probes was collected during the operation of eight onboard SPT-100 thrusters used for north-south and east-west station keeping. These data will be compared to data from past SPT-100 thruster ground testing. An example of the type of data and comparisons being made can be seen in Figure $8 \mathrm{~b}$. This task should be completed and data published at the 2001 International Electric Propulsion Conference.

Task 1.4.5, Alternate Operational Strategies, which has been supported at a low level during this program year, considers the issues associated with pulsed (multiple minute) Hall thruster operation. Pulsed operation of this type is primarily advantageous for low power spacecraft with advanced energy storage. These spacecraft can benefit from the thrust level and efficiency of a high power Hall thruster by operating it impulsively. This type of operation can combine the efficient impulsive orbital maneuvering used with chemical thrusters with the high specific impulse of electric propulsion for overall system advantages. The program year 2001 effort has considered system architecture issues and thermal modeling of thrusters.

Task 1.4.6, Alternate Power/Propulsion Systems, attempts to capitalize on a key strength of the Glenn Research Center. The Power and On-Board Propulsion Division, at NASA GRC, combines both the power and propulsion disciplines allowing both groups to easily leverage each others research. This year two efforts are under way within this task.

First, an integrated test of a dynamic power system with an electric propulsion system was achieved when a Hall-effect thruster was successfully operated with a free-piston Stirling power source. The system is picture in Figure 9. The electrically-heated, $350 \mathrm{~W}$ Stirling converter was designed and built by Stirling Technology Company of Kennewick, WA and provided to GRC under a Small Business Innovative Research (SBIR) agreement. The Hall-effect thruster used was a $300 \mathrm{~W}$ SPT-50. GRC developed the interface Power Processing Unit (PPU), which accepted the 48 V DC Stirling controller output and distributed the power to all the loads of the SPT-50 including the magnets, keeper, heater, and discharge chamber. This test provided an important stepping stone to high 
power, propulsion systems for future robotic science and human exploration missions that will utilize this type of power system. Dynamic power systems with nuclear sources also provide one of the most viable paths for outer planet electric propulsion missions with power levels in excess of $50 \mathrm{~kW}$.

Additionally under this task, a portion of a direct drive effort, selected as part of the Cross Enterprise Technology Development Program NRA, is being conducted. This effort being implemented by Marshall Space Flight Center (MSFC), Science Applications International Corporation (SAIC) and General Dynamics is considering the environment and issues associated with directly powering a Hall thruster from photovoltaic (PV) power on-board a spacecraft. The effort is primarily power system related; however, the issues of assessing the Hall thruster environment and the coupling of the thruster directly with the PV array is supported under this task.

\section{(1.5) Component Level Phenomenological Investigations.}

One task is funded within this area under task 1.5.5, Thruster Internal Plasma and Plume Model Development. Three modeling efforts are underway. The first was selected as part of the Cross-Enterprise Technology Development Program NRA and is being implemented by MIT and Busek Co. Inc. It is a comprehensive modeling effort intended to enhance the understanding of the limiting physics in efficient high specific impulse Hall thruster operation. A multi-dimensional hybrid PIC code is being used. Results are to be compared to experimental data from the University of Michigan P5 and P5-2 thrusters as well as data from a series of Busek Co. thrusters.

The second effort within this task is the development of a finite element continuum based model using a higher-order accurate sub-grid embedded model to efficiently simulate plasma flows. This effort is being conducted by Kettering University and is being investigated for it's computational accuracy advantages and ability to deal with different boundary conditions in a straightforward manner.
The third effort within this task is an empirical performance model developed at GRC. This model was developed to enable the prediction of thrust, specific impulse, and efficiency as design points and operational envelopes depart from current state-of-the-art thrusters. For use at high voltage, the model incorporates the effects of multi charged species. ${ }^{34}$

\section{Focused Program}

The objective of the focused effort is to develop a $50 \mathrm{~kW}$-class Hall propulsion system. System design trade studies have shown that high power Hall thrusters are well suited for providing high thrust with good specific impulse for many applications. $^{22-26}$ This type of propulsion system is enabling for cost and time critical missions for Earth orbital applications as well as HEDS and other space science applications. This effort is sponsored by NASA's Advanced Space Transportation Program at MSFC. Additionally this propulsion system may be enabling for lower power spacecraft when combined with an advanced energy storage device and operated in a pulsed mode as previously mentioned.

The focused program areas are: (2.1) $50 \mathrm{~kW}$ Propulsion System, (2.2) $10 \mathrm{~kW}$ Propulsion System.

\section{(2.1) $50 \mathrm{~kW}$ Propulsion System}

The $50 \mathrm{~kW}$ Propulsion System area has two funded sub-tasks in program year 2001, (2.1.1.1) Thruster Development, and (2.1.1.4) Cathode Development. The thruster development is being conducted via two contracted efforts. The first, with General Dynamics, is providing NASA with multiple variations of a high plasma density thruster. The design will push the stateof-the-art in both power density and performance. The second effort, with Busek Co. Inc., is providing NASA with a thruster design incorporating a non-circular, or racetrack shaped discharge chamber. In theory, the racetrack concept is reconfigurable from $20-50 \mathrm{~kW}$. The contracted efforts are structured to have a base thruster design effort with an optional thruster build effort. Completion of the design efforts is anticipated by October 2001 with a decision on the optional build coming shortly thereafter. The cathode development effort is being conducted in-house at GRC and is leveraging the Space 
Station Plasma Contactor infrastructure. A laboratory model 100 A cathode is presently being tested.

\section{(2.2) $10 \mathrm{~kW}$ Propulsion System}

(2.2) $10 \mathrm{~kW}$ Propulsion System work is limited to reducing the data from the T220 erosion characterization completed early this program year. This test provided insight on lifetime limitations at higher powers and higher discharge voltage $(500 \mathrm{~V})$ than have been previously investigated in the community. A summary of these data can be found in Mason et.al. ${ }^{35}$

\section{Concluding Remarks}

NASA's Hall thruster program consists of both base research and focused development efforts. The base effort addresses issues at a low technology readiness level (TRL) and provides fundamental understanding required for the focused development of high TRL Hall thruster propulsion products. Current questions being addressed by the base research effort include: (1) How does thruster life vary with operating point? (2) How can thruster lifetime and wear rate be most efficiently evaluated? (3) What are the practical limitations for discharge voltage as it pertains to extending the operation of Hall thrusters to high specific impulse (high discharge voltage) and high thrust (low discharge voltage) operation? (4) What are the practical limits for extending Hall thrusters to very high input powers? and (5) What can be done during thruster design to reduce cost and integration concerns? The focused effort is working towards the development of a $50 \mathrm{~kW}$-class Hall propulsion system with a program milestone of a $50 \mathrm{~kW}$ engineering model thruster/system by the end of program year 2006.

\section{References}

1. Sankovic, J.M., Caveny, L.H., Lynn, P.R., "The BMDO Russian Hall Electric Thruster Technology (RHETT) program: From Laboratory to Orbit," AIAA-97-2917, July 1997.

2. Brophy, J.R. Barnett, J.W., Sankovic, J.M., and Barnhart, D.A., "Performance of the Stationary Plasma Thruster: SPT-100," AIAA-92-3155, July 1992.
3. Sankovic, J.M., Hamley, J.A, and Haag, T.W., "Performance Evaluation of the Russian SPT-100 Thruster at NASA LeRC," Proceedings of the 23th International Electric Propulsion Conference, pp. 855-882, September 1993.

4. Hamley, J., Hill, G., and Sankovic, J., "Power Electronics Development for the SPT-100 Thruster," Proceedings of the 23th International Electric Propulsion Conference, pp. 405-415, September 1993.

5. Petrenko, A.N., Hamley, J.A., and Sankovic, J.M., "The Problem of Power Processor and Telemetry/Control Unit Design for Stationary Plasma Thruster," Proceedings of the 24th International Electric Propulsion Conference, pp. 880885, September 1995.

6. Dickens, J.C., "Communications Impact of Hall Effect Plasma Thrusters," PhD Thesis, Texas Tech University, 1996.

7. Randolph, T., Pencil, E., and Manzella, D., "Far-Field Plume Contamination and Sputtering of Stationary Plasma Thruster," AIAA-94-2855, June 1994.

8. Pencil, E.J., Randolph, T., and Manzella, D.H., "End-of-life Stationary Plasma Thruster Far-field Plume Characterization," AIAA-96-2709, July 1996.

9. Myers, R.M. and Manzella, D.H., "Stationary Plasma Thruster Plume Characteristics," Proceedings of the 23th International Electric Propulsion Conference, pp. 893-912, September 1993.

10. Manzella, D.H. and Sankovic, J.M., "Hall Thruster Ion Beam Characterization," AIAA-95-2927, July 1995.

11. Manzella, D.H., "Stationary Plasma Thruster Ion Velocity Distribution," AIAA94-3141, August 1994.

12. Manzella, D.H., "Stationary Plasma Thruster Plume Emissions," Proceedings of the 23th International Electric Propulsion Conference, pp. 913-923, Sept. 1993. 
13. Fischer, G., Kozubsky, K., Kahn, J., Kaufman, H., Sokolov, V., Colbert, T., Day, M., "Design of a High Efficiency Power Processor for the Russian Stationary Plasma Thruster," Proceedings of the 23th International Electric Propulsion Conference, pp. 396-404, Sept. 1993.

14. Garner, C.E., Brophy,J.R., Polk, J.E., Pless, L.C.,"A 5730-Hr Cyclic Endurance Test of the SPT-100," Proceedings of the 24th International Electric Propulsion Conference, pp. 1233-1244, Sept. 1995.

15. Day, M., Maslennikov, N., Randolph, T, and Rogers, W., "SPT-100 Subsystem Qualification Status," AIAA-96-2713, July 1996.

16. Garner, C.E., Mueller, J., Vasin, A., Lasinsky, M., Petrosov, V., Wetch, J., and Britt, N.,"Experimental Evaluation of the T-100-3 Stationary Plasma Thruster and Xenon Propellant System for the RHETT-1 Program," AIAA-96-2968, July 1996.

17. Sankovic, J.M., Haag, T.W., and Manzella, D.M., "Operating Characteristics of the Russian D-55 Thruster with Anode Layer," AIAA-94-3011, June 1994.

18. Garner, C.E., Brophy, J.R., Polk, J.E., Semenkin, A., Garkusha, V., Tverdokhlebov, S., and Marrese, C., "Experimental Evaluation of the Russian Anode Layer Thruster," AIAA-94-3010, June 1994.

19. Oleson, S.R, "Electric Propulsion for Low Earth Orbit Communication Satellites," IEPC 97-148, August 1997.

20. Oleson S.R., et.al. "Advanced Propulsion for Geostationary Orbit Insertion and North-South Station Keeping," (rev.), Journal of Spacecraft and Rockets, Vol. 34, Number 1, pp.22-28, 1997

21. Oleson, S.R., Myers, R.M., "Launch Vehicle and Power Level Impacts on Electric GEO Insertion," AIAA-96-2978, July 1996.
22. Oleson, S.R., "Advanced On-Board Propulsion For RLV Launched Spacecraft," 26th International Electric Propulsion Conference, October 1999.

23. Oleson, S.R., "Advanced Propulsion for Space Solar Power Satellites," AIAA-992872, June 1999.

24. Kerslake, T. W., Gefert, L.P., "Solar Power System Analysis for Electric Propulsion Missions," $34^{\text {th }}$ Intersociety Energy Conversion Engineering Conference, Vancouver, BC, Canada, August 1999.

25. Gefert, L.P., Hack, K.J., "Options for the Human Exploration of Mars using Solar Electric Propulsion," AIP Conference Proceedings, No. 458, pp1275-1280, STAIF-99, Nov. 1999.

26. Oleson, S.R., Sankovic, J.M.., "Advanced Hall Electric Propulsion for Future InSpace Transportation," NASA TM-2001210676.

27. Atlantic Research Corporation, NASA Contract NAS3-99159, Final Report, "Phase I feasibility Study of the 2,300 W Hall Current Thruster," July 2000.

28. Manzella, D.H., Jacobson, D.T., and Jankovsky, R.S., "High Voltage SPT Performance," AIAA-2001-3774, July 2001.

29. Jacobson, D.T., Jankovsky, R.S., Rawlin, V.K., Manzella, D.H., "High Voltage TAL Performance," AIAA-2001-3777, July 2001.

30. Oleson, S.R., "Mission Advantages of Constant Power, Variable Isp Electrostatic Thrusters," AIAA-2000-3413, July 2000.

31. Cardin, J., Otsap, B., "A Digital Xenon Flow Controller Based on $\mathrm{ChEMS}^{\mathrm{T} M}$ Technology," IEPC-99-064, October 1999.

32. Peterson, T., Allen, D., Koester, K., Baranov, V., Romashko, A., "The EXPRESS/T-160E Flight Hardware Development Effort," AIAA-98-3328, July 1998. 
33. Peterson, T., Koester, K., Petrosov, V., Romashko, A., Petrusevich, V., "Update of the EXPRESS/T-160E Flight Hardware Development Effort," AIAA-99-2275, June 1999.

34. Hofer, R.R. and Jankovsky, R.S., "A Hall Thruster Performance Model Incorporating the Effects of a Multi-Charged Plasma," AIAA-2001-3322, July 2001.

35. Mason, L.S., Jankovsky, R.S., Manzella, D.H., "1000 Hours of Testing on a 10 Kilowatt Hall Effect Thruster," AIAA2001-3773, July 2001. 


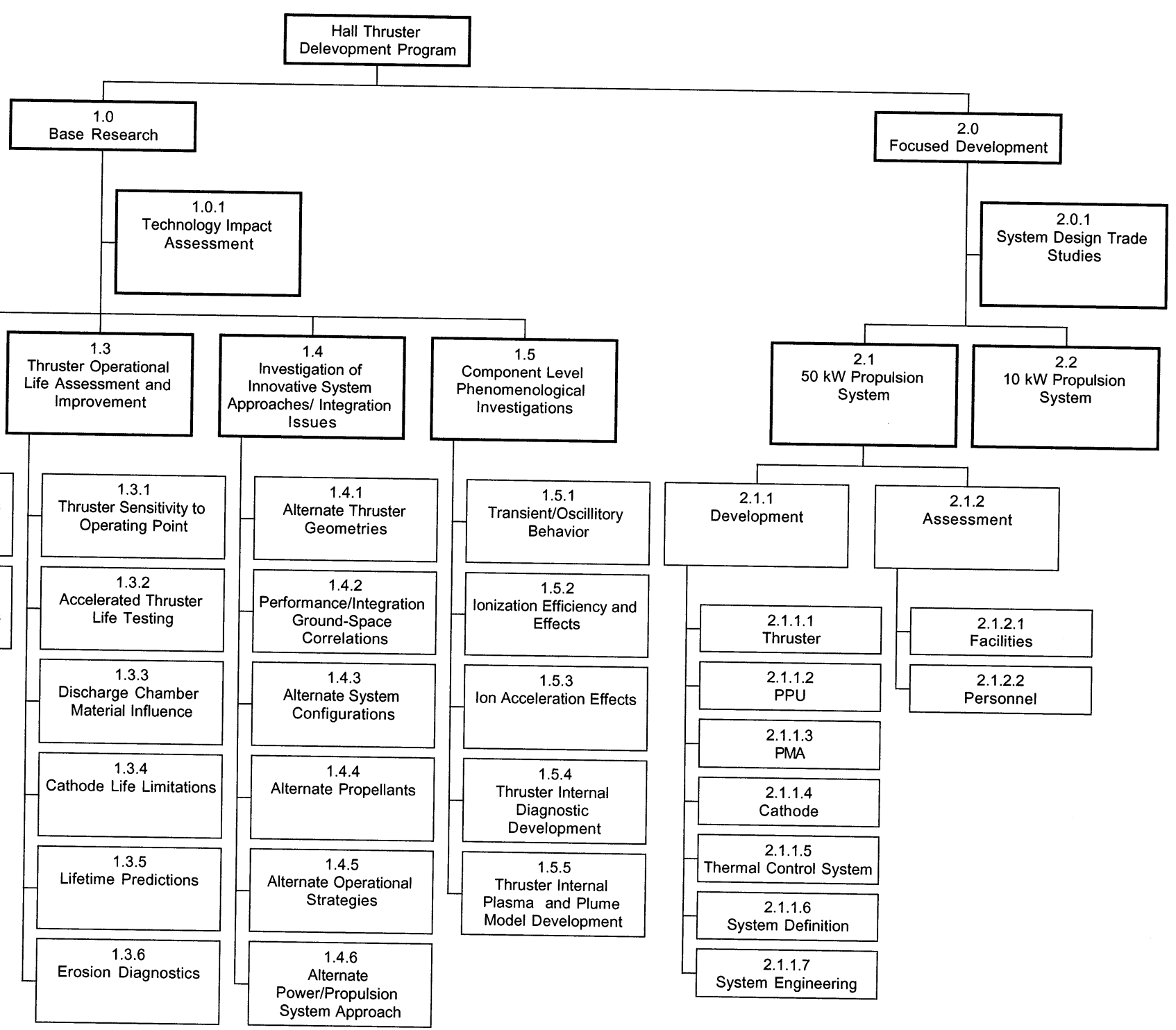

Figure 1 - Hall Propulsion Work Breakdown Structure 


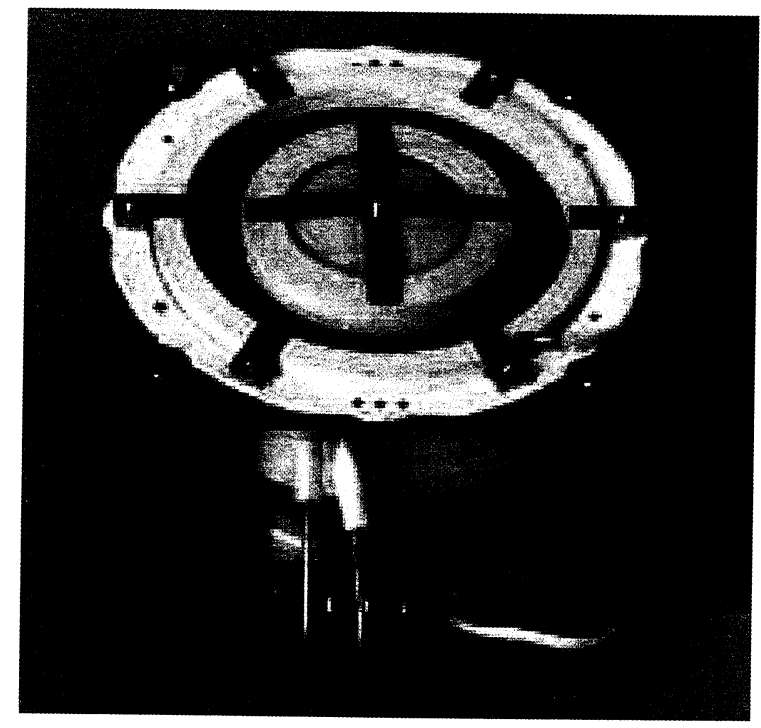

Figure 2 - SPT-1 Single-Stage High Specific Impulse Hall Thruster

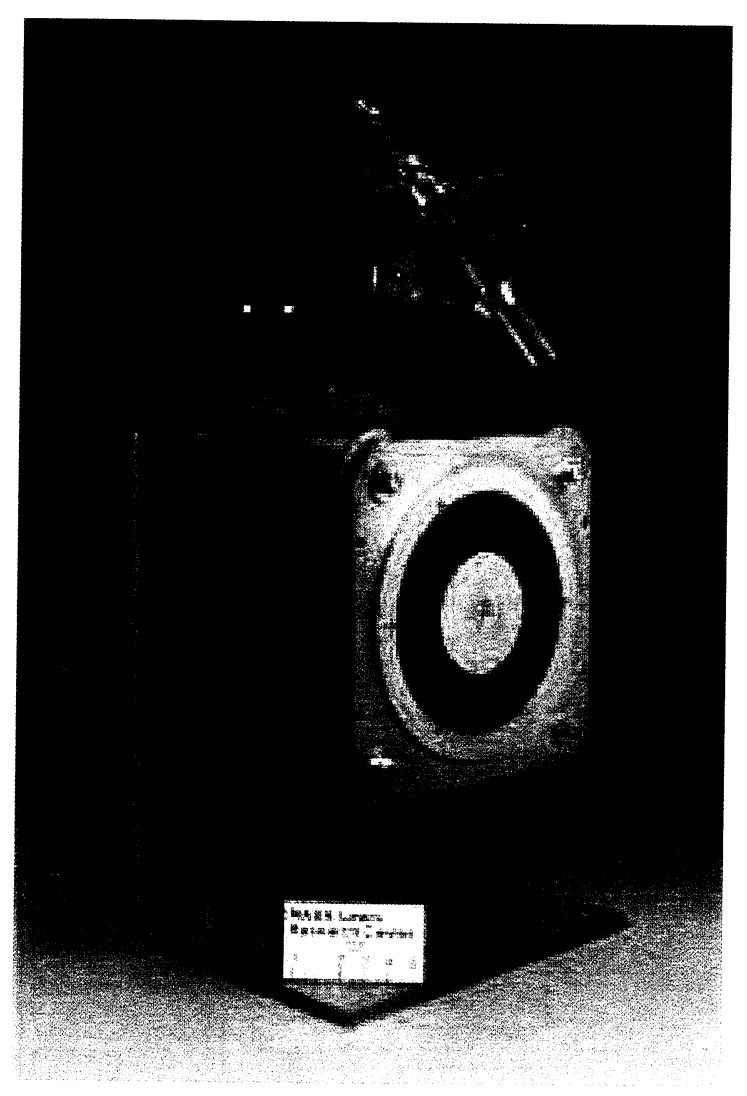

Figure 3 - D-80 High Specific Impulse Two-Stage Hall Thruster 


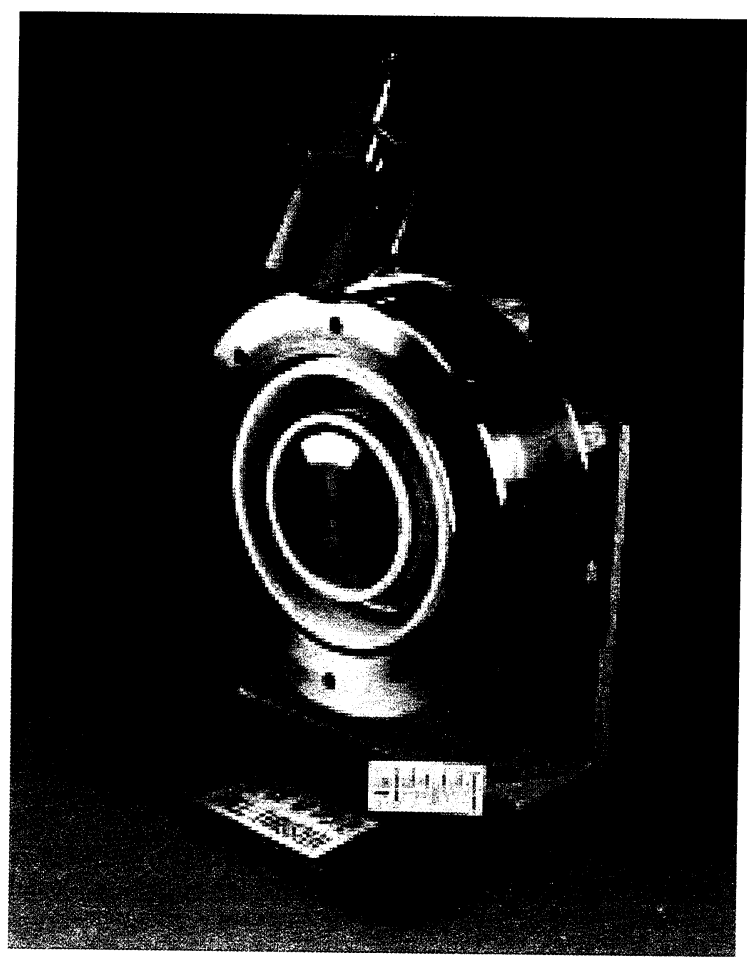

Figure 4 - P5-2 High Specific Impulse Two-Stage Hall Thruster w/ Emitting Electrode

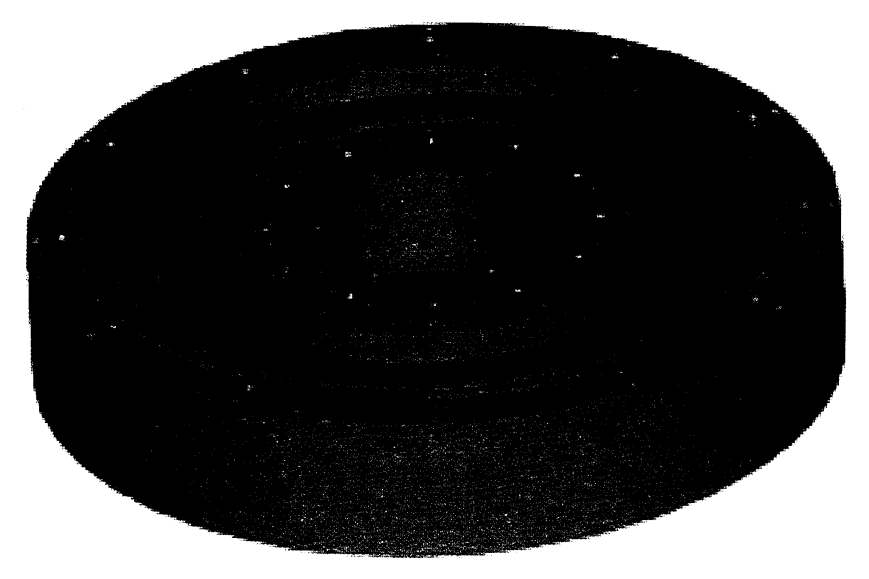

Figure 5 - NASA-457M Solid Model 


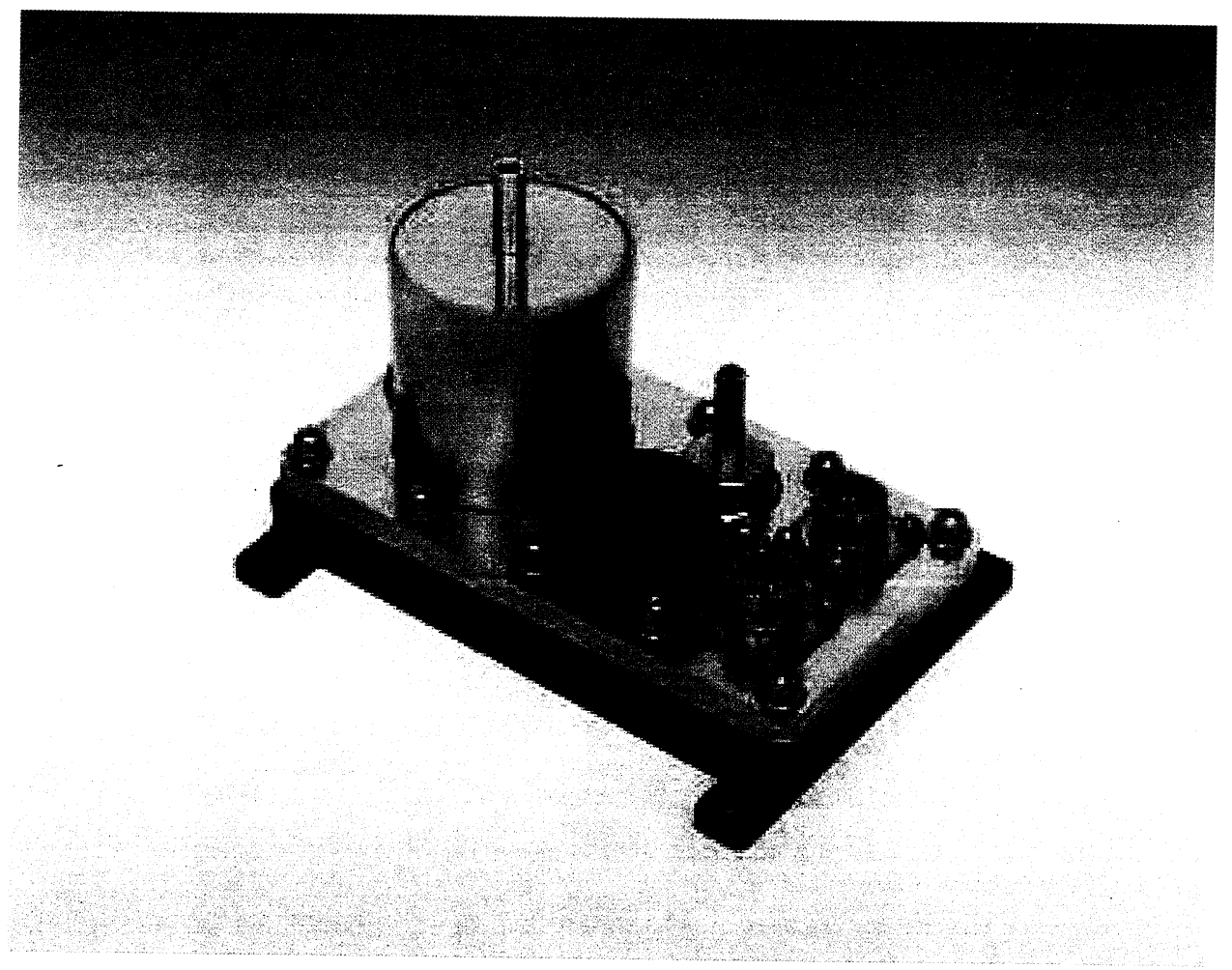

Figure 6 - VACCO Integrated Propellant Management Assembly
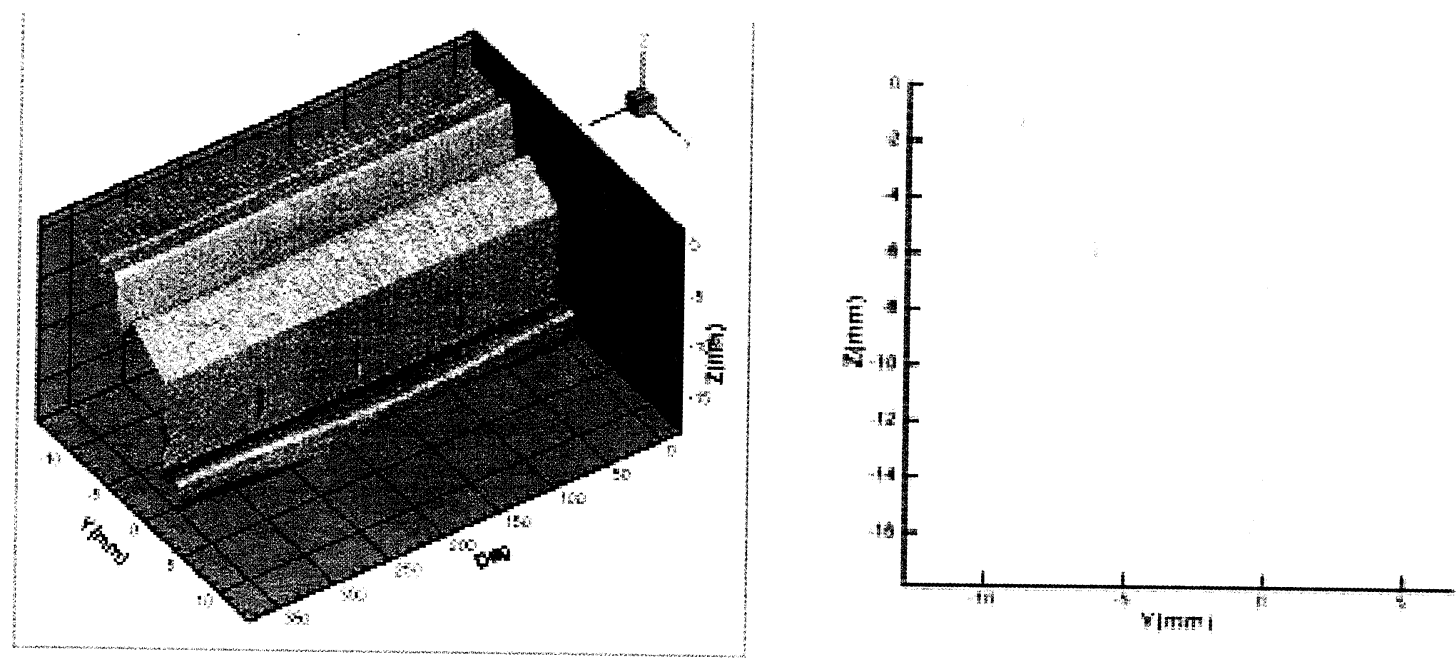

Figure 7 - D-80 Thruster Geometry Measurement 


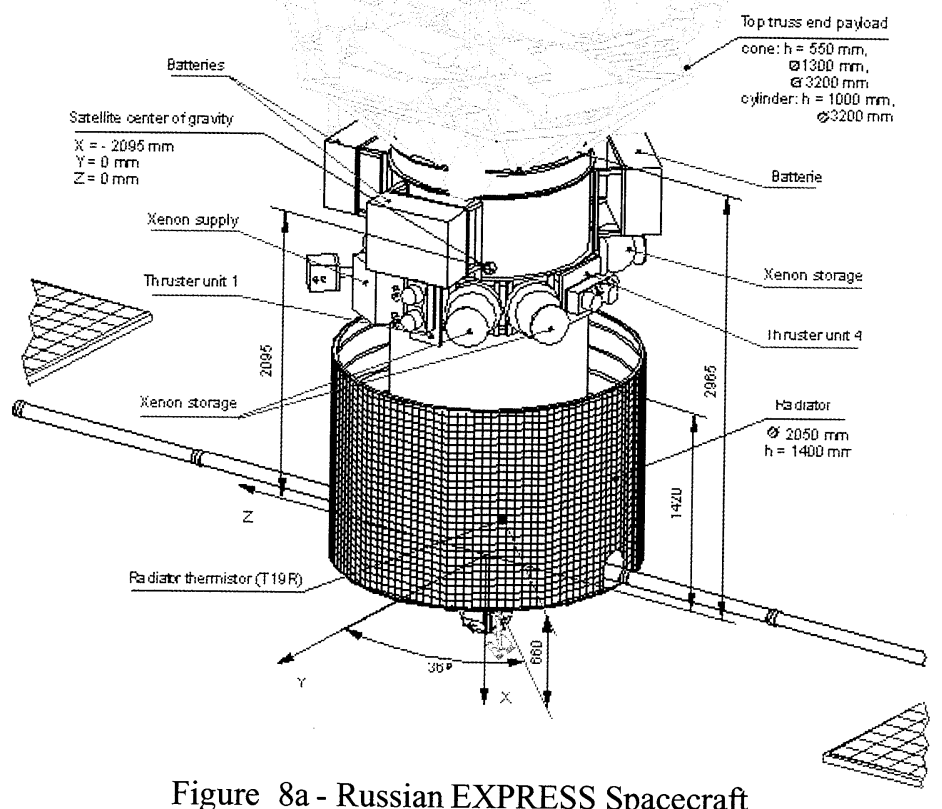

Figure 8a-Russian EXPRESS Spacecraft

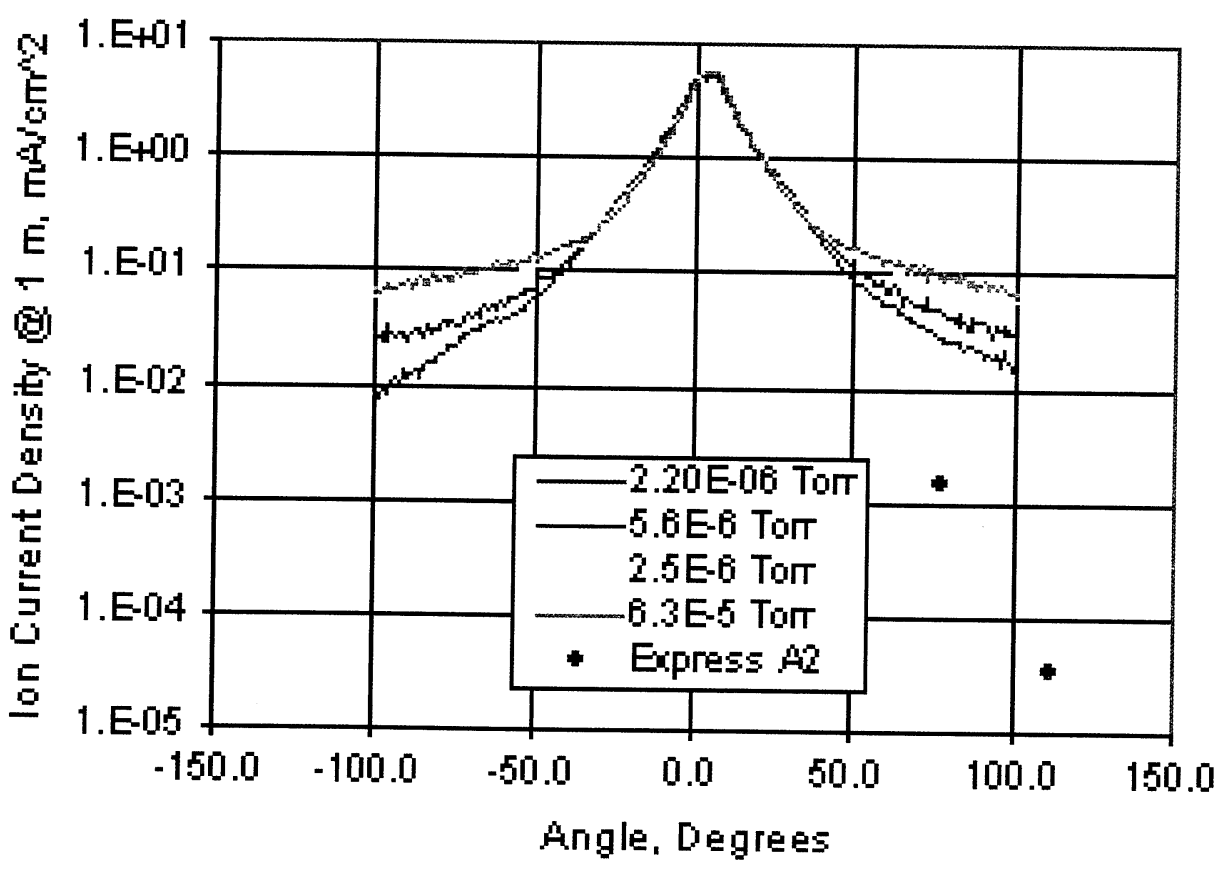

Figure $8 \mathrm{~b}$ - SPT-100 Ground and Space Data 


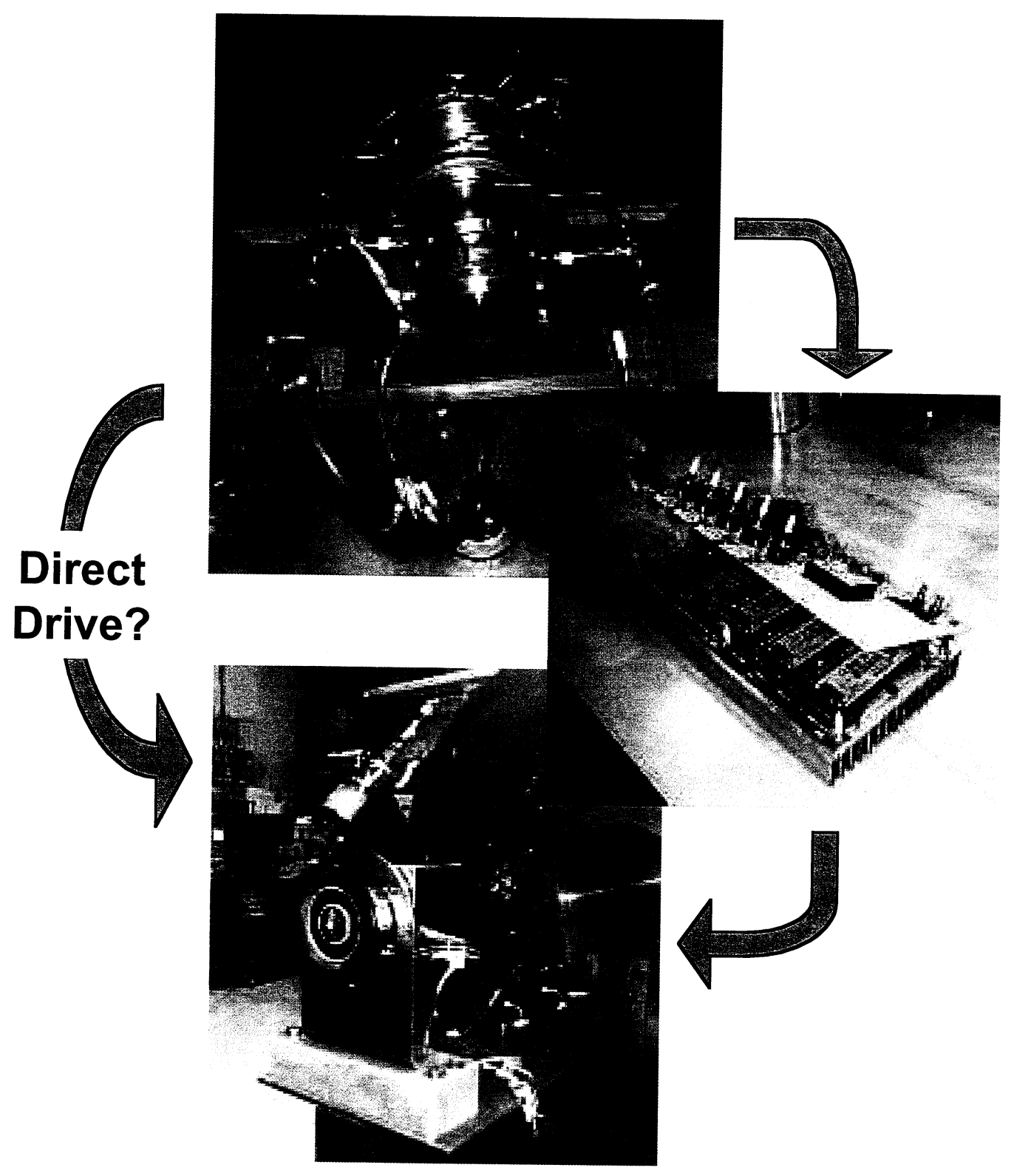

Figure 9 - Stirling-Hall Direct Drive Testbed 

1. AGENCY USE ONLY (Leave blank) 1 2. REPORT DATE

\begin{tabular}{|l|l|l|}
\hline 4. TITLE AND SUBTITLE & $\begin{array}{r}\text { 2. REPORT DATE } \\
\text { December } 2001\end{array}$ & $\begin{array}{r}\text { 3. REPORT TYPE AND DATES COVERED } \\
\text { Technical Memorandum }\end{array}$ \\
\hline
\end{tabular}

5. FUNDING NUMBERS

NASA's Hall Thruster Program

6. AUTHOR(S)

WU-755-B4-05-00

Robert S. Jankovsky, David T. Jacobson, Vincent K. Rawlin, Lee S. Mason, Maris A. Mantenieks, David H. Manzella, Richard R. Hofer, and Peter Y. Peterson

7. PERFORMING ORGANIZATION NAME(S) AND ADDRESS(ES)

National Aeronautics and Space Administration

John H. Glenn Research Center at Lewis Field

Cleveland, Ohio 44135-3191

PERFORMING ORGANIZATION REPORT NUMBER

E-13067

\section{SPONSORING/MONITORING AGENCY NAME(S) AND ADDRESS(ES)}

National Aeronautics and Space Administration

Washington, DC 20546-0001

10. SPONSORING/MONITORING AGENCY REPORT NUMBER

NASA TM-2001-211215

AIAA-2001-3888

\section{SUPPLEMENTARY NOTES}

Prepared for the 37th Joint Propulsion Conference and Exhibit cosponsored by the AIAA, SAE, AIChE, and ASME, Salt Lake City, Utah, July 8-11, 2001. Robert S. Jankovsky, David T. Jacobson, Vincent K. Rawlin, Lee S. Mason, and Maris A. Mantenieks, NASA Glenn Research Center; David H. Manzella, University of Toledo, 2801 W. Bancroft Street, Toledo, Ohio 43606-3328; and Richard R. Hofer and Peter Y. Peterson, QSS Group, Inc., 21000 Brookpark Road, Cleveland, Ohio 44135. Responsible person, Robert S. Jankovsky, organization code 5430, 216-977-7515.

12a. DISTRIBUTION/AVAILABILITY STATEMENT

Unclassified - Unlimited

Subject Category: 20

Distribution: Nonstandard

Available electronically at http://gltrs.grc.nasa.gov/GLTRS

This publication is available from the NASA Center for AeroSpace Information, 301-621-0390.

13. ABSTRACT (Maximum 200 words)

NASA's Hall thruster program has base research and focused development efforts in support of the Advanced Space Transportation Program, Space-Based Program and various other programs. The objective of the base research is to gain an improved understanding of the physical processes and engineering constraints of Hall thrusters to enable development of advanced Hall thruster designs. Specific technical questions that are current priorities of the base effort are: (1) How does thruster life vary with operating point? (2) How can thruster lifetime and wear rate be most efficiently evaluated? (3) What are the practical limitations for discharge voltage as it pertains to high specific impulse operation (high discharge voltage) and high thrust operation (low discharge voltage)? (4) What are the practical limits for extending Hall thrusters to very high input powers? and (5) What can be done during thruster design to reduce cost and integration concerns? The objective of the focused development effort is to develop a $50 \mathrm{~kW}$-class Hall propulsion system, with a milestone of a $50 \mathrm{~kW}$ engineering model thruster/system by the end of program year 2006. Specific program year 2001 efforts, along with the corporate and academic participation, are described.

\section{SUBJECT TERMS}

Hall thruster

15. NUMBER OF PAGES 20 16. PRICE CODE

17. SECURITY CLASSIFICATION OF REPORT Unclassified

\section{SECURITY CLASSIFICATION OF THIS PAGE Unclassified}

19. SECURITY CLASSIFICATION OF ABSTRACT Unclassified 